\title{
Control of Root-Knot Nematode of Eggplant and its Effect on Plant Growth and Yield under Plastic House Condition
}

\author{
Jalal H.S.Ismael ${ }^{1}$, Salam M. Sulaiman', Akram Muhidden², Shorsh M.Faraj ${ }^{2}$ \\ Hazhar Abdul-Khaliq ${ }^{2}$ \\ ${ }^{1}$ Dept. of Horticulture, Faculty of Agricultural Sciences, University of Sulaimani, Sulaimani, \\ Kurdistan Region, Iraq \\ ${ }^{2}$ Sulaimani Agricultural Research Center, Bekrajo, Sulaimani, Kurdistan Region, Iraq.
}

\begin{abstract}
Root - knot nematode (Meloidogyneincognita) is the dangerous disease caused significant effects on eggplant growth and yield. This study was conducted at Bazian, Sulaimani Governorate, Kurdistan Region, Iraq to estimate the population densities and their control, using different methods and with effects on vegetative growth and floral characteristics of the eggplants. An experiment was laid down in a simple randomized complete block design (RCBD) including 9 treatments with three replicates. The results showed that the reproduction factor $(R F)$ of the nematodes in the Nemakey $0.75 \mathrm{ml} \mathrm{m}^{-2}$ and Charge (Humic acid \%15) treatments were 0.00 and 0.50 respectively. Reduction of the juveniles 2 were 100.0 and $81.9 \%$, respectively, so they are considered to be the two best treatments for decreasing the population densities of the nematodes. The highest plant height was $118.7 \mathrm{~cm}$ recorded in the Nemakey $0.75 \mathrm{ml} \mathrm{m}$ treatment, while the Charge gave the largest no. of Leaves/plant (712.7), in the same treatment, the highest amount of chlorophyll was $48.67 \mathrm{mg}^{-1}$, with the shoot weight/plant $(3350 \mathrm{~g})$. However, there were no effects of the all of the treatments on the percentage of leaf dry matter. The largest root length was recorded for the Nemakey $0.75 \mathrm{ml} \mathrm{m} \mathrm{m}^{-2}(50.33 \mathrm{~cm})$ and the root weight

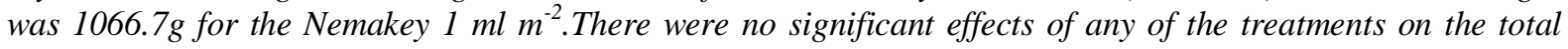
flowers/plant and few effects were observed on the aborted and setting flower/plant, also no. of the days needed for flowering. Charge obtained the highest no. of fruit /plant and the \% of Brix of the fruits, while the Nemakey $2 \mathrm{ml} \mathrm{m}^{-2}$ had significant effects on fruit weight $(\mathrm{g})$, yield $(\mathrm{kg} /$ plant $)$.The percentage of increased yield $(102.58$, 10.60 and 48.04) respectively, compared with the control.
\end{abstract}

Keywords: Root-knot nematode, Meloidogyne, Nemakey, Rugby, Charge, Eggplant growth and yield.

\section{INTRODUCTION}

Eggplant (Solanum melongena L.) is one of the important cultivated vegetable crops in the world. According to the FAO in 2012, 90\% of the eggplant production comes from five countries, including China, India, Iran, Eygpt, and Turkey. The cultivated areas exceed more than 1,600,000 ha., the total yields equal 43,573,139 tons yearly. Iraq (Kurdistan region included) produces 460,000 tons annually preempt the seventh rank of the world eggplant production (FAOSTAT. 2012).

Eggplants attack several pests and diseases like; damping-off and root rots, soft rots, plant viruses and nematodes. The most important diseases in Kurdistan region, Iraq, particularly in Sulaimani are rootknot nematodes (Sulaiman et al., 2016).

Root-knot nematode (RKN) disease comes first among the diseases and pests infecting eggplants in Kurdistan and Iraq (Stephen et al., 2003 and Zwain, 2014). Meloidogyne is regarded to be the most important genus affecting many plant species (Abu-Gharbiah, 2010), and the losses caused by it exceeded 50\% and estimated to be 100 billion dollars annually. Four species of Meloidogyne are wide-spread in the world, which are $M$. javanica, M. incognita, M. hapla and M. arenaria (Menjivar et al., 2012).

Several methods have been applied to control RKN, e.g. chemicals, organic compounds, plant extracts, resistant varieties, and biological control (Sikora and Fernandez, 2005). Chemicals, for their easiness in using their giving relative quick results by the farmers are wider and more applied by them to control RKNs and other plant pathogens (Brand et al., 2010).

In Sulaimani province, there was no real investigation about controlling RKN. Therefore this study comes to investigate the actual causal agent(s) and using alternatives - with chemicals - are so useful and beneficial for vegetable crops, consumers and their farmers themselves and in order to maintain 
agro-ecosystem clean and far away from pollutants. Nemakey (Turkish plant extract mixture product) and some organic compounds, like Humic acid $15 \%$ are excellent methods and alternatives in this regard for solving this problem which the farmers suffered from, especially in protected farming for a long time.

\section{MATERiAls AND MethodS}

An experiment was conducted in a plastic house in Bazian, Sulaimani Province in Bibijak located at $32 \mathrm{Km}$ west of Sulaimani province during the 2013-2014 season. RCBD with three replicates was used, each included 9 plots $(0.8 \times 4 \mathrm{~m})$ in which nine treatments were distributed, distances among blocks and plots were 2 and $1 \mathrm{~m}$ successively. Plastic pipes were used for the purpose of trickle irrigation. Several samples each one $\mathrm{kg}$ weight were taken throughout the field for physical and chemical analysis (Table 1). In order to calculate number of nematodes and some other parameters. One kg soil sample was taken from each plot, and then transferred to the research laboratory in the Department of Horticulture, Faculty of Agricultural Sciences, University of Sulaimani. After mixing the soil samples thoroughly, 100g from each was taken (as subsample) for the purpose of mentioned before.

Table1. Some physical and chemical properties of the plastic house soil prior to planting in 2013 at Bazian Experimental Station/ Sulaimani Agricultural Research Center.

\begin{tabular}{|c|c|c|c|c|c|c|c|c|c|c|c|c|c|}
\hline $\begin{array}{c}\text { Soil } \\
\text { texture }\end{array}$ & \begin{tabular}{|c|} 
E.C./ \\
ds. \\
m.
\end{tabular} & $\mathrm{pH}$ & $\begin{array}{c}\text { Total N } \\
\%\end{array}$ & $\begin{array}{c}\text { Available } \\
\mathrm{P} \\
(\mathrm{ppm})\end{array}$ & $\begin{array}{c}\text { Soluble } \\
\mathrm{K}^{+} \\
(\mathrm{meq} / \mathrm{L})\end{array}$ & $\begin{array}{c}\text { Soluble } \\
\mathrm{Na}^{+} \\
(\mathrm{meq} / \mathrm{L})\end{array}$ & $\begin{array}{l}\text { Soluble } \\
\mathrm{Ca}^{+} \\
(\mathrm{meq} / \mathrm{L})\end{array}$ & $\begin{array}{c}\text { Soluble } \\
\mathrm{Mg}^{+} \\
(\mathrm{meq} / \mathrm{L})\end{array}$ & $\mid \begin{array}{c}\mathrm{CL} \\
(\mathrm{mg} / \mathrm{L})\end{array}$ & $\begin{array}{c}\mathrm{O} . \mathrm{M} \\
\%\end{array}$ & $\begin{array}{c}\mathrm{CaCO}_{3} \\
\%\end{array}$ & $\begin{array}{l}\mathrm{HCO} 3 \\
(\mathrm{meq} / \mathrm{L})\end{array}$ & $\mathrm{CO}^{-3}$ \\
\hline ay loam & 0.30 & 7.3 & 0.1 & 16.5 & 0.13 & 0.19 & 1.3 & 2.8 & 0.3 & 1.2 & 27 & 1.73 & 0.31 \\
\hline
\end{tabular}

Seeds of eggplant (cv. Jawaher-F1) were sown in a nursery close to the plastic house, after the seeds germinating and reaching the physiological ages (4-5 truly leaves), seedlings transferred carefully to their permanent places in the plastic house at a rate of 8 seedling/plot (experimental unit) to one side, with $80 \mathrm{~cm}$ between the seedlings interval. All necessary agricultural processes were carried out for all the treatments. The treatments included:

$\mathrm{T}_{1}$ : Rugby $1 \mathrm{ml} \mathrm{m}^{-2}, \mathrm{~T}_{2}$ : Rugby $1.6 \mathrm{ml} \mathrm{m}^{-2}, \mathrm{~T}_{3}$ : Rugby $2 \mathrm{ml} \mathrm{m}^{-2}, \mathrm{~T}_{4}$ : Nemakey $0.75 \mathrm{ml} \mathrm{m}^{-2}, \mathrm{~T}_{5}$ : Nemakey $1 \mathrm{ml} \mathrm{m}^{-2}, \mathrm{~T}_{6}$ : Nemakey $1.5 \mathrm{ml} \mathrm{m}^{-2}, \mathrm{~T}_{7}$ : Formalin $1 \%, \mathrm{~T}_{8}$ : Control (water spray only) and $\mathrm{T}_{9}$ : Charge, $1.5 \mathrm{ml} \mathrm{m}^{-2}$.

(Note: 1-Formalin1\% (Formaldehyde 37.8\% diluted to 1\%); 2 - Nemakey ${ }^{\circledR}$ [(Turkish natural organic nematicide, Merkez Anadolu Kimya, Turkey-Organic matter 25\%, N=4\%, K2O=5\%, pH: 8-10)]; 3Rugby ${ }^{\circledR} 100$ ME (Cadufos), FMC, Philadelphia, Pennsylvania, USA], 4-Charge ${ }^{\circledR}$ (an organic fertilizer; consists of high $\mathrm{P}+\mathrm{Humic}$ acid $15 \%$, Thailand), all these materials have been purchased from local markets.) Formalin application was carried out two weeks before the seedlings transferring to avoid its detrimental effect, while other treatments were done only a day before planting. All the treatments were applied ones, except for Charge applied thrice.

Diagnosis of the nematode (s): For diagnosing of the root-knot nematode, perineal patterns procedure have been used (Hartman and Sasser,1985), for this purpose root-knot nematode females were collected from the diseased plants in the plastic house at Bazian Experimental Station / Sulaimani Agricultural Research Center.

The parameters have been taken:

-Nematodes parameters:

1-Population densities (Number of Juveniles2 / $100 \mathrm{~g}$ soil) using modified Baermann Funnel technique (Whitehead and Hemming, 1965 from Whitehead, 1998).

2- Reproduction factor $(\mathrm{Rf})=$ final population of the nematodes $(\mathrm{Pf}) /$ initial population of the nematodes $(\mathrm{Pi})$, the data have been obtained were used for giving the host status rating with the quantitative method $(\mathrm{Rf} \geq 1$ means that the plant good host for the nematode, $\mathrm{Rf}=1$ is poor host and $\mathrm{Rf} \leq 0.1$ means non-host according to the standards were pointed out by Sasser et al., 1984 .

-Reduction of the number of nematodes (Juveniles 2) $=$ No. of $\mathrm{J} 2$ of control - No. of $\mathrm{J} 2$ in the treatment

(After10 and 30 days from the applying the treatments /No. of $\mathrm{J} 2$ in control x 100 (Youssef and Lashein, 2013). 
-Plant growth parameters:

\section{A. Vegetative and root growth characteristics:}

1- Plant height $(\mathrm{cm}), 2$ - Number of leaves/plants, 3- Chlorophyll $(\mathrm{mg} / \mathrm{g}$ of a leaf) using Minolta chlorophyll meter model SPAD-502 plus, Japan, 4- Shoot weight (g/plant), 5- \% of leaf dry matters, 6- Root length (cm) and 7- Root weight (g/plant).

\section{B. Flowering characteristics}

1- Number of total flowers/plant, 2- Number of aborted flower/plant, 3- \% of setting flowers, and 4Days needed for flowering (after planting).

\section{Yield characteristics}

1- Number of fruits/plant, 2- Fruit weight (g), 3- Brix (\%) using Digital refractometer 660K, Brix/RI check out, Reichert Company, Japan, and 4- Yield (kg/plant)

\section{Data analysis}

The experiment has been carried out using complete randomized block design (RCBD) with three replicates and means compared according to the Duncan's multiple range test $(\mathrm{p} \leq 0.05)$. XLSTAT computer programming has been used for data analysis.

\section{RESULTS}

Fig.1 shows the effect of different treatments on the population densities and on the reproduction factor (RF). Hence, it shows the clear and significant effects of natural (Mixture of some plant extracts) the nematicide "Nemakey" and Charge (the organic fertilizer). The RF of nematodes in the Nemakey $0.75 \mathrm{ml} \mathrm{m}^{-2}$ and Charge were 0.00 (Fig.1C) and 0.50 and the reduction of the number of juveniles 2 were 100.0 and $81.9 \%$, respectively (Fig 1B), after 30 days of applying treatments, thus indicated that the positive and significant decreasing in the fecundity and the reproduction of the rootknot nematodes (RKNs) has occurred. Since when the Rf equals one or less than one, this means that the ability for reproduction of the RKNs were decreased.

Results in Table 2 show the effect of different treatments on vegetative and root growth. It has been found that average of plant height increased $(48.7 \mathrm{~cm})$ in the case of using Nemakey $0.75 \mathrm{ml} \mathrm{m}^{-2}$ treatment, while these parameters were increased in the number of leaves/plant (712.7), average of chlorophyll content $(48.07 \mathrm{mg})$ and the shoot weight $(3350 \mathrm{~g})$ were increased when Charge was used. On the other hand, Nemakey $1.5 \mathrm{ml} \mathrm{m}^{-2}$ treatment affected on the percentage of leaf dry matter (22.83) in contrast the highest average of root length was $50.83 \mathrm{~cm}$ in the Nemakey $0.75 \mathrm{ml} \mathrm{m}^{-2}$ treatment. Furthermore Nemakey $1 \mathrm{ml} \mathrm{m}^{-2}$ treatment lead to remarkable increasing of root weight $(1066.7 \mathrm{~g})$.

It has been found that there were no significant differences among the treatments in the number of flowers/plant characteristics, although this was more (137.39) in the case of Charge, if compared with the other treatments and control. The number of aborted flower/plant was significantly less in the Nemakey $0.75 \mathrm{ml} \mathrm{m}^{-2}$ and Charge; 16.67 and 18.67 respectively, compared with control treatment (45.70), and vice versa the percentage of the setting flowers in the two above mentioned were much greater; 86.93 and $86.79 \%$ respectively, compared with the other treatments and control. The number of days needed for flowering in Charge was 142, this was the least needed days compared to the treatments and control (Table 3 ).

It was observed from Table 4that Charge had impact on the increasing the number of fruits and the Brix (\%) were 118.67 and 4.80 respectively, while the Nemakey $1.5 \mathrm{ml}^{-2}$ treatment increased the fruit weight/plant, the total yield of the fruits/plant and the percentage of the increased yield $(102.58 \mathrm{~g}$, $10.60 \mathrm{~kg}$ and $48.04 \%$ ) respectively.

\section{DiscuSSIONS}

The results of this experiment revealed that adding of organic fertilizers (Charge) to the soil amended the soil with natural plant products, this lead to increasing in plant growth and yield (Fig.1 and Tables 2,3) of eggplants and suppressing the number of nematode populations (Fig. 1A). 

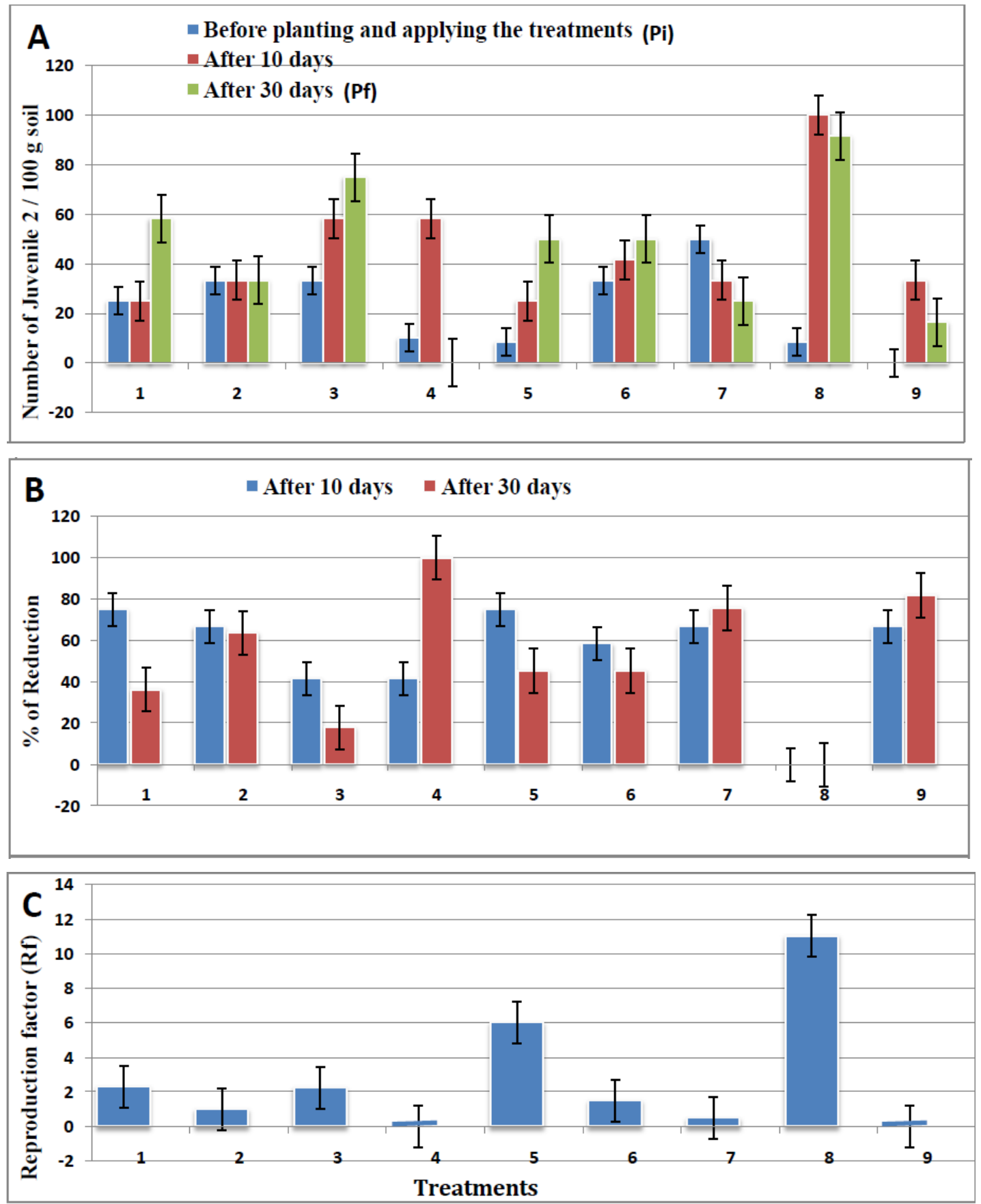

Fig 1. Effect of different treatments $\left\{T 1, T 2\right.$ and T3, are Rugby ${ }^{\circledR} 100 \mathrm{ME}$ at 1, 1.6 and $2 \mathrm{ml} \mathrm{m}^{-2}$; T4, T5 and T6 are Nemakey ${ }^{\circledR} 0.75$, land $1.5 \mathrm{ml} \mathrm{m}^{-2} ;$ T7 is Formalin 1\%; T8 is control (water only); and T9, Charge ${ }^{\circledR} ; .5 \mathrm{ml}$ $\left.\mathrm{m}^{-2}\right\}$ on: A; Nematode (Meloidogyne incognita)population densities (Juvenile 2), $\boldsymbol{B} \%$ of reduction of the number of the nematode, and $\boldsymbol{C}$; Reproduction factor $(R f)=$ Final population density of the nematodes $(P f) /$ Initial population density $(P i)$, the bars are the standard errors $(P \leq 0.05)$.

Results obtained from the Fig. 1 and Tables 2-4 indicate that the organic nematicide (Nemakey) and organic matter (Charge) showed significantly and good effect on reducing Meloidogyne populations in the soil furthermore without any detrimental effect on the beneficial nematode populations (as we observed under light microscope during the root-knot nematode (RKN) counting, in sometimes the number of the beneficial nematodes populations in the tested soil samples reached to more than five times more than the harmful nematodes (RKN). Morales et al., 2011 pointed to the similar result in their investigations. From Table (1) it appeared that the soil was weak in organic matter (OM) and organic nitrogen $(\mathrm{ON})$ and other chemical elements $(\mathrm{OM}$ and $\mathrm{ON}$ were (1.2 and 0.1$) \%$ respectively and available $\mathrm{P}$ was $16.5 \mathrm{ppm}$, soluble $\mathrm{K}^{+}$was 0.13 ). The Nemakey treatment because of its content of organic matter and organic nitrogen and good amount of potassium, caused to supplement the plant complete essential micro and macro elements, which inhances the plants to strengthing themselves and suppressing the root-knot nematodes attacking (Zewain, 2014). 
Control of Root- Knot Nematode of Eggplant and its Effect on Plant Growth and Yield under Plastic House Condition

Table 2. Effects of different treatments for controlling root- knot nematode, Meloidogyne incognita on some vegetative and root growth characteristics of egg plants (cv. Jawaher-F1).

\begin{tabular}{|l|l|l|l|l|l|l|l|}
\hline Treatments & $\begin{array}{l}\text { Plant height } \\
(\mathrm{cm})\end{array}$ & $\begin{array}{l}\text { No of leaves } \\
\text { / plant }\end{array}$ & $\begin{array}{l}\text { Chlorophyll } \\
\text { mg/100g } \\
\text { fresh weight }\end{array}$ & $\begin{array}{l}\text { Shoot weight } \\
\text { (g/plant) }\end{array}$ & $\begin{array}{l}\% \text { of Leaf } \\
\text { dry matter }\end{array}$ & $\begin{array}{l}\text { Root } \\
\text { length } \\
(\mathrm{cm})\end{array}$ & $\begin{array}{l}\text { Root } \\
\text { weight }(\mathrm{g})\end{array}$ \\
\hline T1 & $108.3 \mathrm{a}$ & $258.7 \mathrm{bc}$ & $39.47 \mathrm{bc}$ & $1116.7 \mathrm{~b}$ & $19.65 \mathrm{a}$ & $33.00 \mathrm{bc}$ & $393.3 \mathrm{~b}$ \\
\hline T2 & $102.7 \mathrm{a}$ & $282.0 \mathrm{bc}$ & $39.27 \mathrm{bc}$ & $1150.0 \mathrm{~b}$ & $20.71 \mathrm{a}$ & $27.67 \mathrm{c}$ & $370.0 \mathrm{~b}$ \\
\hline T3 & $104.0 \mathrm{a}$ & $221.0 \mathrm{c}$ & $38.80 \mathrm{c}$ & $866.7 \mathrm{~b}$ & $21.35 \mathrm{a}$ & $34.67 \mathrm{a}-\mathrm{c}$ & $451.0 \mathrm{~b}$ \\
\hline T4 & $118.7 \mathrm{a}$ & $630.0 \mathrm{a}$ & $38.50 \mathrm{c}$ & $2583.3 \mathrm{a}$ & $19.12 \mathrm{a}$ & $50.33 \mathrm{a}$ & $566.7 \mathrm{~b}$ \\
\hline T5 & $117.7 \mathrm{a}$ & $687.3 \mathrm{a}$ & $39.73 \mathrm{bc}$ & $2833.3 \mathrm{a}$ & $21.17 \mathrm{a}$ & $38.33 \mathrm{a}-\mathrm{c}$ & $1066.7 \mathrm{a}$ \\
\hline T6 & $117.0 \mathrm{a}$ & $618.7 \mathrm{a}$ & $40.53 \mathrm{~b}$ & $3033.3 \mathrm{a}$ & $22.83 \mathrm{a}$ & $47.67 \mathrm{ab}$ & $630.0 \mathrm{~b}$ \\
\hline T7 & $110.7 \mathrm{a}$ & $431.3 \mathrm{~b}$ & $36.57 \mathrm{~d}$ & $1456.7 \mathrm{a}$ & $19.31 \mathrm{a}$ & $28.33 \mathrm{c}$ & $478.3 \mathrm{~b}$ \\
\hline T8 & $94.7 \mathrm{a}$ & $191.0 \mathrm{c}$ & $35.13 \mathrm{e}$ & $700.0 \mathrm{~b}$ & $21.99 \mathrm{a}$ & $25.33 \mathrm{c}$ & $486.7 \mathrm{~b}$ \\
\hline T9 & $115.7 \mathrm{a}$ & $712.7 \mathrm{a}$ & $48.67 \mathrm{a}$ & $3350.0 \mathrm{a}$ & $20.25 \mathrm{a}$ & $41.00 \mathrm{a}-\mathrm{c}$ & $681.7 \mathrm{~b}$ \\
\hline
\end{tabular}

"T1, T2 and T3 are Rugby ${ }^{\circledR} 100 \mathrm{ME}$ at $1,1.6$ and $2 \mathrm{ml} \mathrm{m}^{-2}$ respectively, T4, T5 and T6 are Nemakey ${ }^{\circledR} 0.75,1$ and $1.5 \mathrm{ml} \mathrm{m}^{-2}$ respectively, $T 7$ is Formalin 1\%, T8 is control (water only), and T9, Charge; $1.5 \mathrm{ml} \mathrm{m}^{-2}$ applied thrice during the growing season.

**Each number is the mean of three replications. Values in column followed by the same letter are not significantly different $(P \leq 0.05)$ according to Duncan's Multiple Range Test.

Table 3. Effect of different treatments for controlling root knot nematode, Meloidogyne incognita on some flowering characteristics of eggplants (cv. Jawaher-F1).

\begin{tabular}{|c|c|c|c|c|}
\hline Treatments & $\begin{array}{c}\mathrm{N}^{\circ} \text { of Total flower / } \\
\text { plant }\end{array}$ & $\begin{array}{c}\mathrm{N}^{\text {** }} \text { of aborted } \\
\text { flowers / plant }\end{array}$ & $\begin{array}{c}\text { \% of setting } \\
\text { flowers }\end{array}$ & $\begin{array}{c}\text { Days needed for } \\
\text { flowering (after planting) }\end{array}$ \\
\hline $\mathrm{T} 1$ & $119.34 \mathrm{a}$ & $20.67 \mathrm{ab}$ & $82.78 \mathrm{ab}$ & $159.33 \mathrm{c}$ \\
\hline $\mathrm{T} 2$ & $136.22 \mathrm{a}$ & $42.89 \mathrm{ab}$ & $68.46 \mathrm{ab}$ & $161.00 \mathrm{~d}$ \\
\hline $\mathrm{T} 3$ & $126.00 \mathrm{a}$ & $32.67 \mathrm{ab}$ & $74.57 \mathrm{ab}$ & $160.67 \mathrm{~d}$ \\
\hline $\mathrm{T} 4$ & $124.67 \mathrm{a}$ & $16.67 \mathrm{a}$ & $86.93 \mathrm{a}$ & $155.00 \mathrm{~b}$ \\
\hline $\mathrm{T} 5$ & $122.00 \mathrm{a}$ & $23.34 \mathrm{ab}$ & $78.47 \mathrm{ab}$ & $155.00 \mathrm{~b}$ \\
\hline $\mathrm{T} 6$ & $119.34 \mathrm{a}$ & $25.56 \mathrm{ab}$ & $78.20 \mathrm{ab}$ & $142.00 \mathrm{a}$ \\
\hline $\mathrm{T} 7$ & $128.89 \mathrm{a}$ & $23.34 \mathrm{ab}$ & $80.94 \mathrm{ab}$ & $161.00 \mathrm{~d}$ \\
\hline $\mathrm{T} 8$ & $124.45 \mathrm{a}$ & $45.70 \mathrm{~b}$ & $63.54 \mathrm{~b}$ & $160.00 \mathrm{~cd}$ \\
\hline $\mathrm{T} 9$ & $137.34 \mathrm{a}$ & $18.67 \mathrm{a}$ & $86.79 \mathrm{a}$ & $142.00 \mathrm{a}$ \\
\hline
\end{tabular}

* T1, T2 and T3 are Rugby® $100 \mathrm{ME}$ at $1,1.6$ and $2 \mathrm{ml} \mathrm{m-2}$ respectively, T4, T5 and T6 are Nemakey® $0.75,1$ and $1.5 \mathrm{ml} \mathrm{m}$-2 respectively, $T 7$ is Formalin 1\%, T8 is control (water only), and T9, Charge; $1.5 \mathrm{ml} \mathrm{m-2} \mathrm{applied}$ thrice during the growing season.

**Each number is the mean of three replications. Values in column followed by the same letter are not significantly different $(P \leq 0.05)$ according to Duncan's Multiple Range Test.

Table 4. Effect of different treatments for controlling root knot nematode, Meloidogyne incognita on some yield characteristics of eggplants (cv. Jawaher-F1).

\begin{tabular}{|c|c|c|c|c|c|}
\hline Treatments* & $\begin{array}{c}\text { No of fruit } \\
\text { /plant** }\end{array}$ & $\begin{array}{c}\text { Fruit } \\
\text { weight } \\
(\mathrm{g})\end{array}$ & $\begin{array}{c}\text { Brix } \\
(\%)\end{array}$ & $\begin{array}{c}\text { Yield } \\
\text { Kg / plant }\end{array}$ & $\begin{array}{c}\text { \% of the } \\
\text { increased } \\
\text { yield }\end{array}$ \\
\hline T1 & $98.67 \mathrm{ab}$ & $87.69 \mathrm{a}$ & $4.47 \mathrm{~b}$ & $8.60 \mathrm{~cd}$ & 16.77 \\
\hline T2 & $93.33 \mathrm{ab}$ & $89.93 \mathrm{a}$ & $4.47 \mathrm{~b}$ & $8.30 \mathrm{~cd}$ & 15.92 \\
\hline T3 & $93.33 \mathrm{ab}$ & $84.79 \mathrm{a}$ & $4.43 \mathrm{~b}$ & $7.90 \mathrm{de}$ & 10.33 \\
\hline T4 & $108.00 \mathrm{a}$ & $83.33 \mathrm{a}$ & $4.50 \mathrm{~b}$ & $9.00 \mathrm{bc}$ & 25.69 \\
\hline T5 & $98.67 \mathrm{ab}$ & $98.89 \mathrm{a}$ & $4.47 \mathrm{~b}$ & $9.70 \mathrm{ab}$ & 35.47 \\
\hline T6 & $103.33 \mathrm{ab}$ & $102.58 \mathrm{a}$ & $4.83 \mathrm{~b}$ & $10.60 \mathrm{a}$ & 48.04 \\
\hline T7 & $96.00 \mathrm{ab}$ & $84.46 \mathrm{a}$ & $4.47 \mathrm{~b}$ & $8.10 \mathrm{~cd}$ & 13.12 \\
\hline T8 & $78.67 \mathrm{~b}$ & $92.80 \mathrm{a}$ & $4.23 \mathrm{~b}$ & $7.16 \mathrm{e}$ & - \\
\hline T9 & $118.67 \mathrm{a}$ & $81.74 \mathrm{a}$ & $4.80 \mathrm{a}$ & $9.70 \mathrm{ab}$ & 35.47 \\
\hline
\end{tabular}

* T1, T2 and T3 are Rugby® $100 \mathrm{ME}$ at $1,1.6$ and $2 \mathrm{ml} \mathrm{m}$-2 respectively, T4, T5 and T6 are Nemakey® $0.75,1$ and $1.5 \mathrm{ml} \mathrm{m}$-2 respectively, T7 is Formalin 1\%, T8 is control (water only), and T9, Charge; $1.5 \mathrm{ml} \mathrm{m-2} \mathrm{applied}$ thrice during the growing season.

**Each number is the mean of three replications. Values in column followed by the same letter are not significantly different $(P \leq 0.05)$ according to Duncan's Multiple Range Test. 
The chemonematicides (Rugby) also relatively have been reducing the number of RKN, but however causes inadmissible and toxicity effects on the plant growth status (Al-Agidi and Al-Mashhadaani, 2013). Charge, although it improves the eggplant growth and physiological status (Sulaiman et al., 2016), it also induces the plant, creating the so-called secondary metabolites (Phytoalexins), which triggers the plants more resistance to the root-knot nematode infection. Oka and Pivonia, 2002 stated that organic fertilizers contain formulations releasing this form of nitrogen in the soil that can suppress nematode populations. Worthily applying the organic fertilizers to the farmer's soils conserving and promoting soil aggregation and impeding the nematode juveniles movement (Melba and Onweremadu, 2009).

\section{ACKNOWLEDGEMENT}

We are grateful to the Directorate of Sulaimani Agricultural Research Center (DSARC) / Ministry of Agriculture and Water Resources (MOAWR), Kurdistan Region Government, Iraq for providing us funds to complete this work and for their technical supports.

\section{REFERENCES}

[1] Abu-Gharbiah, W. I.; Alhazmi; A. S. Istephan and A. A. Dawaba. 2010. Plant Nematode in Arab Countries. Wael publication house, $1142 \mathrm{pp}$.

[2] Al-Agidi, F. J. and A. I. H. Al-Mashhadaani. 2013. The efficacy of some biological and chemical agents to control root-knot nematode (Meloidogyne spp.) on eggplants. The Iraqi Journal of Agricultural Sciences, 44(3): 348 - 354.

[3] Brand, D. C.; R. A. Soccol; A. Sabu and S. Roussos. 2010. Production of fungal biological control agents through solid state fermentation: A case study on Paecilomyceslilacinus against root-knot nematodes. MicologíaAplicada International, 22(1): 31 - 48.

[4] FAOSTAT 2012. Final 2012 Data and Preliminary 2013 Data for 5 major commodity aggregates Now available. http://faostat.fao.org/site/339/default.aspx

[5] Hartman, K. and J. N. Sasser. 1985. Identification of Meloidogyne species on the basis of differential host test and perineal pattern morphology. Pp.69 - 77, In: K. R. Barker; C. C. Carter; J. N. Sasser, (Eds). An Advanced Treatise on Meloidogyne. Vol. II. Methodology. Raleigh, NC, North Carolina States Graphics.

[6] Stephan, Z. A.; A. M. Turkey; H. I. Abbas; H. B. Aawood and B. E. George 2003. Effect of super phosphate fertilizer and some animal fertilizers and mycorrhizal fungi mixed with Karbela desert soil in activity of Meloidogyne spp. on tomato plants. Iraqi Journal of Agriculture, 34(5): $171-176$.

[7] Melbah, C. N. and E. Onweremadu. 2009. Effect of organic and mineral fertilizer inputs on soil and maize grain yield in an acidity soil in Abakaliki-South Eastern Nigeria. American Eurasia Journal of Agronomy, 2 (1): 7-12.

[8] Menjivar, R. D.; A. A. Dababat and R. A. Sikora. 2012. Biological control of Meloidogyne incognita on cucurbitaceous crops by the non-pathogenic endophytic fungus Fusarium oxysporum strain 162. International Journal of Pest Management, 57(3): 70-72.

[9] Morales.I., A. Benavides and J.Garcia. 2011. Efecto del proyectorzh contra Meloido gynein cógnitaen tomate.20th International Symposium for nutrition and vegetables. De Riego, Vol. 9, No.56: 70-72. (Abstract in English).

[10] Oka, Y. and S. Pivonia. 2002. Use of ammonia-releasing compounds for control of the root-knot nematode. Nematology, 4: 65-71.

[11] Sasser, J. N.; C. C. Carter and K. N. Hartmann 1984.Standardization of host stability studies and reporting of resistance to root - knot nematodes, Raleigh, North Carolina, USA.A cooperative publication of the North Carolina State University and the United States Agency for International Development, 7 pp.

[12] Sikora, R. A. and E. Fernandez. 2005. Nematode parasites of vegetable. In: Luc, M.; R. A. Sakura; J. Bridge (Eds). Plant parasitic nematodes in subtropical and tropical agriculture. CABI publishing, UK, pp. $39-319$.

[13] Sulaiman, S. M.; A. M. Abdul rahman; A. M. Ahmad and N. E. Muhammad. 2016. Effect of sowing dates and black plastic mulching on flowering growth and yield of Eggplants (cv. 
JAWAHER- F1) in plastic houses. The paper accepted for publication in Journal of Kirkuk University for Agricultural Sciences, 7(4). (In Arabic)

[14] Whitehead, A. G. 1998. Plant Nematode Control. CAB, UK, 384 pp.

[15] Youssef, M. M. A. and A. M. S. Lashein 2013. Effect of cabbage (Brassica oleracea) leaf residue as a biofumigant, on root-knot nematode, Meloidogyne incognita infecting tomato, Journal of Plant Protection Research, 53(3): 271-274.

[16] Zewain, Q. K. 2014. Evaluation of some chemical nematicides and organic formulations in management of root knot nematode Meloidogynespp. on egg plant. Journal of Tikrit University for Agricultural Sciences, 3rd Scientific Conference for Plant Production, 14(special issue):814.

Citation: J. H S. Ismael et al. "Control of Root- Knot Nematode of Eggplant and its Effect on Plant Growth and Yield under Plastic House Condition", International Journal of forestry and Horticulture (IJFH), vol. 3, no. 2, p. 7, 2017, http://dx.doi.org/10.20431/2454-9487.0302004.

Copyright: (C) 2017 Authors. This is an open-access article distributed under the terms of the Creative Commons Attribution License, which permits unrestricted use, distribution, and reproduction in any medium, provided the original author and source are credited. 